\title{
COMMENT
}

\section{BARGAINING POWER AND UNCONSCIONABILITY: A SUGGESTED APPROACH TO UCC SECTION 2-302}

Section 2-302 of the Uniform Commercial Code provides that a court may refuse to enforce a contract, or any clause thereof, which it finds to have been unconscionable at the time it was made. I The section is new to the law of sales, ${ }^{2}$ and neither the Code nor the common law provides an established definition of unconscionability. ${ }^{3}$ Nonetheless, analysis of the section's purpose, as expressed in the Comment thereto, indicates that there are definite and reasonable limits to the intended scope of the section's application. The Official Comment states that the section is intended to prevent "oppression and unfair surprise," ${ }^{4}$ two rather common abuses of bargaining power by the stronger party to a contract."

1 If the court as a matter of law finds the contract or any clause of the contract to have been unconscionable at the time it was made the court may refuse to enforce the contract, or it may enforce the remainder of the contract without the unconscionable clause, or it may so limit the application of any unconscionable clause as to avoid any unconscionable result.

UNIFORM COMAMERCIAL CODE $\$ 2-302(1)$. As to the meaning and significance of $\S 2-302$, see generally Note, 45 IowA L. REv. 843 (1960); Note, 109 U. PA. I. REv. 401 (1961) ; Note, 45 VA. L. REv. 583 (1959); Note, 63 Y ALE L.J. 560 (1954); 58 Dick. L. Rev. 161 (1954); Comment, 18 U. CHI. L. Rev. 146 (1950). See also 1 HawKLAND, A TRansactional GutDe to THE UNIFORM Commercial Code 44-48 (1964).

2 UnIFORM Commercial CODE \$2-302, Comment 1.

3 Note, 45 IowA L. REv. 843, 847, 850 (1960). The notion of unconscionability, to be sure, has antecedents in the law. Courts have often refused to enforce contracts which appear to be grossly unfair, but they have done this by manipulating doctrines of assent and consideration and techniques of construction to attain the desired result of nonenforcement. Indeed, one of the avowed purposes of the section is to provide courts with a means of achieving the same results in such cases without having to resort to such manipulation, which often distorts the growth of contract concepts. UNIFORM COMMERCIAL CODE $\$ 2-302$, Comment 1 . Similarly, while equity courts have often refused to grant specific performance where the result would be unconscionable, Note, 109 U. PA. L. REv. 401, 406 (1961), such cases do not provide an established definition.

In Hume v. United States, 132 U.S. 406, 411 (1889), the Supreme Court defined an unconscionable contract as one "such as no man in his senses and not under delusion would make on the one hand, and as no honest and fair man would accept on the other ..." This definition, however, has not been considered to be of much help in providing a workable test under $\$ 2-302$.

This lack of definition in the section has led some commentators to suggest that the section gives courts too much power to alter private agreements, and that it poses a threat to commercial stability. E.g., King, Suggested Changes in The Uniform Commercial Code-Sales, 33 ORE. L. REv. 113, 115 (1954). For these reasons California, when it enacted the Code, refused to adopt \$2-302. California State Bar Committee on the Commercial Code, The Uniform Commercial Code, 37 CALIF. ST. B.J. 119,136 (1962).

4 Uniform Commerctar CoDe \$2-302, Comment 1.

5 The Comment states that the section's purpose is not to disturb "the allocation of risks due to superior bargaining power." Ibid. As demonstrated in the text accompanying notes 6-8 infra, this statement, if taken literally, somewhat contradicts the purpose of preventing oppression. See 79 HARv. L. REv. 1299, 1301 (1966). The real force of the statement, it would seem, is cautionary: a contract is not necessarily unconscionable because one party obtains advantages by means of superior bargaining power. 
The relation of the first of these abuses, oppression, to disparate bargaining power is obvious. An oppressive contract is one in which party A forces party $B$ to accept burdensome terms, not justified by commercial necessities, as the cost of obtaining the contract's benefits. $B$ accepts the oppressive terms, although aware of the consequences, because his bargaining power is such that he must do business on A's terms or not at all.

The other evil at which the section is aimed, unfair surprise, is also related to the relative bargaining positions of the parties. ${ }^{6}$ Unfair surprise is most easily illustrated by the fine print contract. In many modern commercial agreements, the document containing the basic agreement of the parties also contains a myriad of fine print terms explaining and qualifying the parties' rights and obligations. In many such situations it is likely that the party to whom the contract is offered does not read the fine print; and if he attempts to read it he may find it written in highly technical legal language which is either misleading or altogether incomprehensible.? When the party learns, subsequent to his agreeing to the contract, that the fine print contains a provision which he had not known was in the contract, he is surprised within the meaning of the Comment to section 2-302. If he should reasonably have known and understood the relevant terms, then the surprise is not "unfair." But when his ignorance is reasonable, and the other party knew or should have known at the time the contract was made that such ignorance was likely, then the surprise is unfair. ${ }^{8}$ Thus it appears that a party who is able to include in the contract terms not likely to be read or understood occupies a superior bargaining position which can yield advantages as unjustifiable as those obtainable by a party with a superior economic position.

This analysis indicates that the Official Comment gives more guidance to the interpretation of section 2-302 than has been thought.9 Its application is to be limited to those contracts whose unfairness arises from unequal bargaining power between the parties. The two aspects of unconscionability identified by the Official Comment to section 2-302 thus share a common characteristic: they both are related to inequality of bargaining power between the parties. It might therefore be suggested, on the basis of the Official Comment, that the section is not intended to apply to all contracts which are "unfair," but only to those contracts in which unfairness can be said to have resulted from inequality of bargaining power between the parties.

Two recent cases seem to have employed this analysis in construing the concept of unconscionability embodied in section 2-302. In Henningsen

6 This relationship has generally been overlooked. See, e.g., 79 HARV. L. REv. 1299, 1301 (1966).

T See, for example, the ingeniously shrunken fine print on the back of a standard bill of lading.

8 Traditionally, under the doctrine of objective intent, unfair surprise was irrelevant. See, e.g., Restatenent, Contracts $\$ 70$ (1932); Note, 63 HaRv. L. Rev. 494, 495 (1950).

จ See, e.g., Note, 109 U. PA. L. REv. 401, 403-04 (1961). 
v. Bloomfield Motors, Inc., ${ }^{10}$ an automobile owner and his wife sued the manufacturer and the dealer for personal injuries suffered in an accident caused by a defect in the automobile's steering mechanism. The defense was based in part on a provision in the contract of sale limiting liability for breach of warranty to the replacement of defective parts. The court held that the provision was void as against public policy, and granted recovery. In reaching its decision, the court relied heavily on two facts. The first was that the type of disclaimer used by the defendant Chrysler Corporation was used by all automobile manufacturers, so that even if plaintiff had actually known its effect he would have had to accept it or forego the purchase of an automobile. ${ }^{11}$ The second fact was that the purchaser could not reasonably have known of the existence of the disclaimer of liability - for the clause, hidden in fine print, was not pointed out to plaintiff by the dealer at the time of the purchase, and even if it had been its language was such that a reasonable layman might not have understood its legal effect. ${ }^{12}$ Although the Code was not in effect in New Jersey when this case was decided, the court's citation of section 2-302 suggests that the case presented the types of abuses which that section was intended to prevent. ${ }^{13}$

The notion of surprise appears, in even more striking fashion, in Williams v. Walker-Thomas Furniture Co. ${ }^{14}$ In that case defendant Williams purchased a 514 dollar stereo set from plaintiff on an installment contract which provided that the amount owed on the contract would be added on to any amount already owed by defendant, so that payments made were credited proportionately to all outstanding debts. The effect of the contract was, on one hand, to prevent the balance due on the first purchase from being satisfied until the amount due on all items was satisfied, and, on the other hand, to secure the debt incurred on the last item purchased by all items previously purchased. Prior to the transaction in question the purchaser had, since 1957, made purchases totalling approximately 1300 dollars, of which she had paid all but 164 dollars. Shortly after purchasing the stereo set she defaulted on her payments and plaintiff moved to replevy all items purchased since 1957 . The lower court denied defendant's contention that the add-on provision was unconscionable, on the ground that the District of Columbia did not recognize a doctrine of unconscionability..$^{15}$

1032 N.J. 358, 161 A.2d 69 (1960).

11 Id. at $389-91,161 \mathrm{~A} .2 \mathrm{~d}$ at $86-87$.

12 Id. at 400,161 A.2d at 93. For a much-cited discussion of judicial treatment of fine print clauses prior to the enactment of the Code, see Note, 63 HARv. L. REv. 494 (1950).

$13358 \mathrm{~N} . J$. at $404,161 \mathrm{~A} .2 \mathrm{~d}$ at 95 . As one commentator has suggested, the Henningsen holding-that the clause violated public policy-rests on narrower grounds than those provided by $\$ 2-302$ which may be applied to contracts whose abuses may not be so egregious as to invoke the condemnation of public policy. Posel, Sales and Sales Financing, 16 Rutgers L. REv. 329, 335-36 (1962).

14350 F.2d 445 (D.C. Cir. 1965); 54 GEo. L.J. 703 (1966); 79 HARv. L. REv. 1299 (1966); 12 How. L.J. 164 (1966).

15 Williams v. Walker-Thomas Furniture Co., 198 A.2d 914 (D.C. Ct. App. 1964). 
The court of appeals reversed and remanded for findings of fact as to whether the contract was unconscionable. The court held that Congress' action in adopting the Uniform Commercial Code and section 2-302 for the District of Columbia, although taken subsequent to the contract in question so that 2-302 was not directly applicable, gave the court authority to recognize as part of the jurisdiction's common law the doctrine of unconscionability.

One of the factors which the court deemed important was defendant's "obvious lack of education" and her consequent inability to understand the terms of the contract. ${ }^{16}$ Even though there was no indication that plaintiff had made a deliberate attempt to "hide" the add-on provision, as had been done with the disclaimer clause in Henningsen, Mrs. Williams was surprised because her "obvious lack of education" made her unable to understand the terms of the contract. This surprise was unfair because the seller, who knew or should have known that Mrs. Williams did not understand the contract, seemingly made no attempt to explain its terms to her.

Both Henningsen and Williams thus represent situations in which a court, using the type of analysis obviously intended under section 2-302, refused to allow a party with superior bargaining power the benefits of unfair contractual advantages achieved by means of its superiority. That inequality of bargaining power should be a sine qua non to a finding of unconscionability may be seen by an analysis of the relation between section 2-302 and the doctrine of freedom of contract. The freedom of contract doctrine rests on the assumption that parties to a contract are the best judges of the value to themselves of the reciprocal obligations in the contract. ${ }^{17}$ This assumption is realistic only so long as the contract represents real bargaining between parties with freedom of choice and consequent ability to negotiate in a meaningful sense. But when one party, either because of lack of economic power or inability to understand what is contained in the contract, does not have real bargaining power, the contract's conscionability becomes a matter of grace with the stronger party, rather than a matter of negotiation. In this case, the assumption that the parties have really agreed that the reciprocal obligations are adequate is no longer tenable. ${ }^{18}$ It is at this point that the rationale of section 2-302 becomes pertinent. Thus the purpose of the section is not to subvert the doctrine of freedom of contract but to limit it to situations where the assumption as to reciprocity of benefit is realistic. ${ }^{19}$ Where the assumption

16350 F.2d at 449 . The court also noted that defendant had no free choice as to the terms of the contract, so that plaintiff had the bargaining power to insist on oppressive terms (or so it could be found on remand).

17 See, e.g., Henningsen v. Bloomfield Motors, Inc., 32 N.J. 358, 389-91, 161 A.2d $69,86-87(1960)$, and authorities there cited.

$18 \mathrm{Ibid}$. For a good general discussion of the problems of adhesion contracts see Wilson, Freedom of Contract and Adhesion Contracts, 14 INT'L \& CoMr. L.Q. 172 (1965). For an approach to these problems alternative to that provided in $\$ 2-302$, see Meyer, Contracts of Adhesion and the Doctrine of Fundanental Breach, 50 VA. L. REv. 1178 (1964).

19 See, e.g., Note, 45 Iowa L. Rev. 843-46 (1960). 
is not realistic, where the contract is not the product of a true bargain, then-and, it is submitted, only then-is a court justified under section $2-302$ in examining the terms of the contract to determine whether they are so unconscionable as to require denial of enforcement.

The foregoing analysis demonstrates that a court should not consider the question whether or not a contract is unconscionable, even though it appears unfair, unless it first determines that at the time the contract was made there was such an inequality of bargaining power that one party could include terms in the contract which were not justifiable on grounds of commercial necessity. This proposition does not mean, however, that when the bargaining element is lacking a court should then always refuse to enforce, under 2-302, what appears initially to be an unfair bargain. This is strikingly illustrated by analysis of two recent cases, In re Dorset Steel Equip. Co. ${ }^{20}$ and In re Elkins-Dell $M$ fg. Co. ${ }^{21}$ Both cases involved the validity of a security agreement in a bankruptcy proceeding. Since the relevant facts of the cases were identical, and since they were decided by the same referee on identical grounds, they will be considered together.

The contract provided that Fidelity America Financial Corporation (Fidelity) would lend funds to a corporation (debtor), the loans to be secured, as they were made, by the debtor's accounts receivable. The contract further provided: Fidelity would lend money equal to seventy-five per cent of the face value of the debtor's accounts receivable deemed acceptable by Fidelity; although Fidelity had sole discretion to decide which accounts receivable constituted acceptable collateral, debtor could not market any of its receivables to any other lender without Fidelity's consent; debtor could not borrow money from anyone else without Fidelity's consent; debtor had to pay a high interest rate on money borrowed, including a yearly fixed minimum interest payment unrelated to the amount actually borrowed; and debtor could not suspend business or go into voluntary bankruptcy without Fidelity's consent.

When the debtor went into involuntary bankruptcy, Fidelity filed its claim as a secured creditor. The referee, while acknowledging Fidelity's claim as a creditor, held that the security provisions enumerated above were unconscionable and therefore invalid, and that Fidelity had to share in the assets as an unsecured creditor. He noted that at the time the agreement was made the debtor was in such a precarious financial situation that no one except Fidelity would lend it the necessary funds. Consequently, he inferred that Fidelity had such a superiority in bargaining position that it was able to dictate the terms on which it would lend money.22 Fidelity, he concluded, used its position to exact concessions which were so onerous as to be unconscionable, thus rendering the agreement unenforceable in bankruptcy.

202 UCC Rep. Serv. 1016 (Bankruptcy No. 26532, E.D. Pa. August 2, 1965).

212 UCC Rep. SeRv. 1021 (Bankruptcy No. 26109, E.D. Pa. July 22, 1965).

222 UCC REP. SERv. at 1019-20. 
Even if the referee's two factual assumptions-that the debtor had virtually no bargaining power and that the terms of the contract taken in a general business context were so onerous as to be unconscionable-were accurate, his conclusion seems unjustified. The factor giving rise to the debtor's lack of bargaining power-a condition precedent to a finding of unconscionability ${ }^{23}$-was its precarious financial condition. Yet it is that very factor which makes the contract at least arguably conscionable. The limitations on the debtor's power to borrow, the high fixed interest charge and the other limitations on the debtor's freedom of action may well have been necessary to protect Fidelity's investment.

A situation analogous to that in the bankruptcy cases can be hypothesized in the Williams case. If Mrs. Williams had been known to treat her acquisitions poorly-giving them particularly hard wear, neglecting to repair them or allowing her children to mutilate them-the value of any particular item purchased might well have depreciated so rapidly that it would not constitute adequate security for the debt. In this situation the add-on provision might have been commercially justifiable as a necessary protection for the furniture company's investment-perhaps, denied this means of securing the debt, neither Walker-Thomas nor any other furniture company would have been willing to sell Mrs. Williams a stereo set on time. In this hypothetical case, as in the bankruptcy cases, the very factor which contributes to one party's lack of bargaining power might justify contract terms which, in the abstract, appear unconscionable.

Thus it appears that the lack of bargaining power as to a particular contract may cut two ways with respect to the issue of unconscionability. The very factors which lead to the lack of bargaining power may serve to justify the apparently unconscionable terms. Section 2-302(2) provides a means for a court to take account of this possibility:

When it is claimed or appears to the court that the contract or any clause thereof may be unconscionable the parties shall be afforded a reasonable opportunity to present evidence as to its commercial setting, purpose and effect to aid the court in making the determination. ${ }^{24}$

It would seem, however, that even if such evidence is not presented-as in the bankruptcy cases ${ }^{25}$ - the court, in determining unconscionability, should make an effort to judge the contract in its commercial setting. This is not to say, however, that simply because a particular contract represents the only terms on which the superior party desires to do business, it is necessarily commercially justifiable. In the bankruptcy cases, for example, even though Fidelity might have needed more than ordinary control over

23 See pp. 999, 1001-02 supra.

24 UNIFORM COMMERCIAL CODE \$2-302(2).

25 One factor which may have accounted for the referee's apparent failure to consider the possible commercial justification for the contracts was that in both cases Fidelity failed to file a brief. See In re Dorset Steel Equip. Co., 2 UCC REP. SERv. 1016, 1017 (Bankruptcy No. 26532, E.D. Pa. August 2, 1965); In re Elkins-Del1 Mfg. Co., 2 UCC REP. SERv. 1021, 1022 (Bankruptcy No. 26109, E.D. Pa. July 22, 1965). 
the debtor's business as a reasonable protection for its investment, a court need not conclude that an effort by Fidelity to charge what the traffic would bear is necessarily justified by its statement that it would have refused to do business on lesser terms. Sections 1-102(3) ${ }^{26}$ and 2-103 ${ }^{27}$ make clear that the standard of conduct sanctioned by the Code is that of good faith: "honesty in fact and the observance of reasonable commercial standards of fair dealing in the trade." 28

A further question remains concerning the court's power under section 2-302. In the hypothetical situation outlined above concerning the destructive Mrs. Williams, ${ }^{29}$ assume that the add-on is justifiable in that particular case as a commercially reasonable way for the seller to protect himself, although it would be unconscionable in the usual case. Is the court therefore obligated to enforce the contract even though Mrs. Williams did not understand its terms? Commentators discussing section 2-302 imply an affirmative answer. ${ }^{30}$ Their argument seems to be that the section should only be employed where the harshness of the terms cannot be justified under the circumstances of the particular case. This is not however a necessary conclusion. Faced with a contract which is apparently unconscionable, a court might well say that even though its proponent may be able to justify it because of the unique facts of the particular case, i.e., the commercial setting, he cannot prevail unless he can show in addition that he made the consequences of the contract clear to the other party. Thus where a contract appears unconscionable, unfair surprise would justify a court's finding a contract unenforceable even though its provisions can be justified as commercially reasonable. The justification for such a view is that even when a person is in such a position that the only way he can obtain the benefit of a particular transaction is to submit to unusually harsh terms, he should nonetheless have the choice of deciding whether the price he must pay is too great. Moreover, it does not seem unjust to require the proponent of the contract, who presumably knows that the contract is particularly harsh, to make sure that the other party realizes the consequences of committing himself to its terms. ${ }^{31}$

This approach raises still another question: what should be the extent of the obligation to disclose? In a transaction between businessmen, such

26 UNIFORM COMMERCIAL CODE $\$ 1-102(3)$.

27 UNiform Commercial Code $\$ 2-103(1)(b)$.

28 Ibid.

29 See p. 1003 supra.

30 E.g., Note, 63 Harv. L. Rev. 494, 504 (1950); 58 Dick. L. Rev. 161 (1954).

31 Such an approach to the application of $\$ 2-302$ has a particular advantage for the court. Much comment has centered around the fact that a court may often be particularly ill-equipped to judge whether or not contracts are justifiable in their commercial setting. See, e.g., Note, 18 U. CHI. L. REv. 146, 152 (1950). Yet it does not seem unlikely to assume that many putatively unconscionable contracts, particularly in the field of consumer sales, would never be made if the parties both knew and understood what they were getting into. A rule which would make the failure to disclose adequately the consequences of a contract to the other party sufficient grounds to deny enforcement of particularly harsh, albeit justifiable, terms might very well lead to a situation in which many borderline contracts would not be made at all, thus relieving the courts of the obligation of wrestling with their justifiability. 
as those in the bankruptcy cases, the proponent's duty might be no more than to refrain from employing practices designed to hide harsh terms, on the assumption that all businessmen may reasonably be required to read straight-forward contracts. ${ }^{32}$ But the situation is different in the area of consumer sales. Particularly where the purchaser is uneducated, a situation most subject to contractual abuse, it is unlikely that anything but the most central features of the contract are read or understood. If section $2-302$ is to provide adequate protection for these people, ${ }^{33}$ the standard of disclosure imposed on sellers must be higher than in the transaction between businessmen. However, the greater the duty put on the seller, the less willing he may be to do business at all. The setting of the standard must include, therefore, a balancing between the desire for consumer protection and the desire to provide even the least reasonable or least educated consumer some opportunity to purchase the commodities and services which are available to his more fortunate fellow citizens. While this is a real concern, developing standards of disclosure in various commercial settings seems no more difficult than other kinds of judicial balancing, such as establishing standards of care in the tort law.

Thus it would seem desirable for courts to adopt the position that where the terms of a contract seem particularly harsh, although justifiable because of the unique fact situation, they will nonetheless be unenforceable under section 2-302 if the proponent of the contract does not take adequate steps to disclose the consequences of the harsh terms to the other party. But if this is a reasonable position the inevitable question arises: what justification is there for restricting it to contracts whose terms appear unconscionable in the abstract? Why should there not be a requirement that adequate disclosure be made of all terms in all contracts? A short answer is that where the terms of a contract seem clearly fair it is not "unconscionable" for a court to hold a party to the agreement to which he has manifested assent. Such an answer to a large extent begs the question by defining unconscionability in an arbitrary manner. Nonetheless, section 2-302 at this stage of its development is generally considered a limited remedy for the more intolerable abuses of contract power ${ }^{34}$-not a total reworking of traditional contract doctrine. To urge that the section be employed to assure that there is subjective assent to a contract, even when a unique commercial setting is not needed to justify its terms, would seem to strike too deeply at the firmly established notion that objectively manifested assent is the relevant factor in the formation of contracts.

32 In Dorset Steel the referee noted that the contract involved was written in fine print and technical language. 2 UCC REP. SERv. at 1020. Such an observation is not particularly relevant in that case as it seems likely that the principals of Dorset Steel, even if they could not understand the contract themselves, had access to a lawyer who could explain the consequences of the contract to them.

33 The area of consumer sales is one in which $\S 2-302$ can be of particular benefit. For a somewhat horrifying account of the degree to which consumers generally, and uneducated consumers in particular, are subject to unscrupulous business practices, with virtually no legal protection, see Comment, 114 U. PA. L. REv. 395 (1966).

34 See authorities cited note 1 supra. 